\title{
ENTRE A RELIGIÃO E 0 SECULARISMO: INCURSÃO NAS MEMORIAS DO PROFESSORADO CATARINENSE DOS ANOS 1960
}

\author{
BETWEEN THE RELIOGION AND THE SECULARISM: INCURSION IN THE \\ MEMORIES OF TEACHERS FROM SANTA CATARINA IN THE 1960'S
} ENTRE LA RELIGIÓN Y LA SECULARIDAD: INCURSIONAR EN LA CÁTEDRA
MEMORIAS CATARINENSES DE LOS ANÕS 1960

Marilândes Mól Ribeiro de Melo* marilandes.melo@ifc-araquari.edu.br

Ione Ribeiro Valle ${ }^{* *}$ ione.valle@ufsc.br

Rafaela Azevedo de Souza*** rafaela_pedagogia-ufsc@hotmail.com

REVISTA PEDAGÓGICA
Revista do Programa de Pós-graduacão em Educacão da Unochapecó Universidade Comunitária da Região de Chapecó | Chapecó-SC, Brasil Como referenciar este artigo: MELO, M. M. R.; VALLE, I. R.; SOUZA, R. A. Entre a religião e o secularismo: incursão nas memórias do professorado catarinense dos anos 1960. Revista Pedagógica, Chapecó, v. 18, n. 38, p. 114-135, maio/ago. 2016. DOI: http://dx.doi.org/10.22196/rp.v18i38.3390

RESUMO: Este artigo analisa questões que envolvem o binômio religião/laicidade a partir de memórias do professorado aposentado da Rede Estadual de Ensino de Santa Catarina no contexto da década de 1960. As análises apoiam-se em estudo bibliográfico, na sua representação sobre a religião e a laicidade e em argumentos fundamentados pela Sociologia e História da Educação. Requerer do professorado um exercício profissional fundamentado na laicidade, demonstra a busca da homogeneização, da regulação e do controle de um sistema de ensino que deveria, em tese, ser habitado por professores(as) secularizados(as). Assim, nossos estudos demostram que a presença da religião, sobretudo católica, e dos estudos religiosos no cotidiano da escola laica, gratuita e obrigatória atravessa a segunda metade do século XX e permanece forte até os dias atuais. Focamos a presença da religião e os primeiros vestígios da laicidade na educação básica catarinense, além de possíveis confrontos das duas vertentes entre o professorado.

Palavras-chave: Religião. Laicidade. Professorado Catarinense. Formação Docente.

ABSTRACT: This article analyzes questions which involve the binomial religion/secularism based on memories of the retired teachers from the State Teaching System of Santa Catarina in the context of 1960's. The analyses are supported by bibliographic study in its representation about the religion and the secularism, as well as by arguments founded on Sociology and on History of Education. Requiring from the teachers a professional practice based on secularism shows the search for homogenization, for regulation and for the control of an educational system which, in thesis, should be formed by secular teachers. Thus, our studies demonstrate that the presence of religion, especially the Catholicism, and the presence of the religious studies in the daily life of the obligatory, public (free) and secular school cross the second half of $2 \mathrm{O}^{\text {th }}$ century and keep strong up today. We focused on the presence of religion and on the first signs of secularism in the Basic education in Santa Catarina, besides on possible confrontation of the two sides among the teachers.

Keywords: Religion. Secularism. Teachers from Santa Catarina. Docent's Training.

RESUMEN: Este artículo analiza cuestiones relacionadas con el binomio religión/laicismo a partir de las memorias del profesorado jubilado de la Red de Educación del Estado de Santa Catarina, en el contexto de la década de 1960. Los análisis se apoyan en estudio bibliográfico, en su representación de la religión y el laicismo, y en argumentos fundamentados por la Sociología y la Historia de la Educación. Requerir del profesorado una práctica profesional fundamentado en el laicismo demuestra la búsqueda de la homogeneización, de la regulación y del control de un sistema educativo que debería, en teoría, ser habitado por profesores(ras) secularizados(as). Por lo tanto, nuestros estudios demuestran que la presencia de la religión, especialmente católica, y los estudios religiosos en la escuela laica cotidiana, gratuita y obligatoria atraviesa la segunda mitad del siglo XX y sigue siendo fuerte hasta la actualidad. Nos centramos en la presencia de la religión y los primeros vestigios de la laicidad en la educación básica de Santa Catarina, además de posibles enfrentamientos entre las dos vertientes entre el profesorado.

Palabras clave: Religión. El Laicismo. Profesorado de Santa Catarina. Instrucción Docente. 
${ }^{*}$ Doutora em Educação (UFSC), Mestre em Educação (UFSC) e Licenciada em Pedagogia (2005) pela Universidade Federal de Santa Catarina com habilitação em Supervisão Escolar e Séries Iniciais.

\begin{abstract}
** Pós-doutora pela École des Hautes Études en Sciences Sociales - Paris (2014), Doutorado em Ciências da Educação pela Université René Descartes - Paris V Sorbonne (2001), Mestrado em Ciências Sociais pela Universidade Federal de Santa Catarina (1991) e graduação em Pedagogia pela Universidade do Planalto Catarinense (1976). Atualmente é professora associada do Centro de Ciências da Educação da Universidade Federal de Santa Catarina e Bolsista de Produtividade em Pesquisa do CNPq - Nível 2.
\end{abstract}

\footnotetext{
**** Mestranda do Programa de Pós-Graduação em Educação da Universidade Federal de Santa Catarina (UFSC), linha Sociologia e História da Educação (SHE) sob orientação do professor Santiago Pich. Graduação em Pedagogia (2014) pela Universidade Federal de Santa Catarina (UFSC). Integrante do grupo de pesquisa Laboratório de Pesquisas Sociológicas Pierre Bourdieu (LAPSB).
}

\footnotetext{
${ }^{1}$ Este trabalho foi originalmente apresentado na sétima edição do Congresso Brasileiro de História da Educação, ocorrido em Cuibá/MT e publicado nos anais deste Congresso. Para esta revista, as ideias foram ampliadas, permitindo uma abordagem mais verticalizada do tema.

2 Este projeto, desde sua primeira edição, foi renovado pelo $\mathrm{CNPq}$ como bolsa de produtividade em pesquisa (PQ), com o título "Memória docente e justiça escolar: os movimentos de escolarização e profissionalização do magistério em Santa Catarina” para desenvolvimento entre março de 2012 e fevereiro de 2015 e, também, com o título "Educação escolar, justiça social e memória docente: as múltiplas faces das desigualdades escolares em Santa Catarina”, que está em vigor desde março de 2015, com duração até fevereiro de 2018 .
}

\section{INTRODUÇÃ̃ ${ }^{1}$}

"A presença do religioso na sociedade está sempre relacionada com os dispositivos estatais, apesar ou por causa da laicidade"

(GIUMBELLI, 2008, p. 81).

"Mesmo admitindo a irreversibilidade do processo de secularização, não cremos, na verdade, que seja possível, no mundo de hoje, definir uma resposta única para o problema da relação entre educação e religião, designadamente no que se refere à escola pública"

(PINTASSILGO, 2011; BELLI, 2008, p. 9).

$\mathrm{O}$ artigo que ora se apresenta tem como objetivo identificar e analisar, nos escritos do professorado primário aposentado da Rede Estadual de Ensino de Santa Catarina, noções relativas à religião e à laicidade. O binômio religião/ laicidade será explorado a partir das suas memórias sobre a referida Rede, no contexto da década de 1960. Esta temática integra os estudos desenvolvidos pelo projeto Memória Docente: os impactos do movimento de escolarização em Santa Catarina sobre a carreira docente, as identidades profissionais e o trabalho pedagógico de professores da Rede Estadual de Ensino, desenvolvido entre os anos de $2009 / 2012^{2}$. Este projeto destinou-se a "recuperar, registrar e analisar" a memória docente de professores(as) catarinenses que atuaram na educação pública e que se encontram na condição de aposentados(as). Até o momento (2015), tal projeto recolheu em torno de 1.000 questionários, compondo um acervo que permite investigar uma diversidade de aspectos relacionados à formação docente no Estado, tendo em vista sua abrangência de abordagens. Esses questionários são considerados, por nós, como registro de memórias; logo, por meio deles, buscamos desvendar "[...] as magias e os perigos dos trabalhos da memória, sempre mais e sempre menos do que um dia aconteceu" (NEVES, 2002, p. 10). Em sua proposta, procurou se aproximar de um número significativo de professoras e professores por meio de testemunhos grafados em questionários. Esses(as) docentes atuaram em diferentes níveis da educação básica, da Rede Estadual de Ensino do Estado de Santa Catarina. O desenvolvimento do projeto funcionou (e funciona), também, como uma estratégia para levantamento de dados sobre o lugar desses agentes, na tessitura social e educacional catarinense. Foram recolhidas 820 unidades entre os meses de novembro de 2009 a janeiro de 2013, além de outros documentos que compõem o acervo, por exemplo, memoriais descritivos (MELO, 2014).

As análises apoiam-se no estudo bibliográfico e na representação do professorado sobre religião e laicidade, dada por argumentos propostos pela Sociologia e História da Educação. Peter Burke (1980, p. 9) nos ajuda a compreender que 
3 Ao término dos anos 1950, Celso Ramos, organizou o "Seminário Sócio-Econômico" no Estado, entre os anos de 1958/1959. Esse Seminário direcionou sua campanha para o governo "[...] com o propósito de definir uma ideologia de desenvolvimento com a participação da população de Santa Catarina" (AMORIM, 1984, p. 38). Amorim (1984, p. 38) ainda argumenta que "[...] o Seminário representou mais que um evento socioeconômico. Representou uma estratégia política, que se configurou posteriormente em proposta de governo". O Seminário revelou a carência de recursos humanos, o que era um ponto vulnerável para o desenvolvimento. Isso colaborou para solidificar a consciência da necessidade de dar novos rumos para Santa Catarina. Eleito pela coligação PDS/PTB (Aliança Social Democrática), Celso Ramos executou suas propostas de governo por meio de Plano de Metas do Governo (PLAMEG). Este Plano "[...] contava com assessorias especializadas para implementar no Estado uma administração planejada" (MELO, 1990, p. 42). Conforme consta no Trabalho do encontro dos Governadores, de 1961, os objetivos do PLAMEG se resumiam à "execução, [ao] aperfeiçoamento e [à] atualização de obras e serviços públicos" e "promoção de desenvolvimento econômico-social do Estado" (Separata da Mensagem, 1961, p. 181). No aspecto que diz respeito à educação como subsidiária do desenvolvimento econômico e social do Estado, o Governo de Celso Ramos, por meio das ações do PLAMEG, criou o Centro de Estudos e Pesquisas Educacionais (Cepe), responsável pelo desenvolvimento da pesquisa educacional e prestação de assistência técnica ao corpo docente de Santa Catarina como modo de tornar as políticas governamentais mais científicas e produtivas nessa esfera. Ao Cepe, caberia desenvolver pesquisas sobre a educação catarinense, a fim de que os resultados dessas pesquisas subsidiassem as políticas públicas para a educação em Santa Catarina.
[...] a Sociologia pode bem ser definida como o estudo da sociedade humana, com ênfase na generalização da sua estrutura. A História pode ser definida como o estudo das sociedades humanas, com ênfase nas diferenças entre elas e nas mudanças verificadas ao longo do tempo em cada uma. As duas abordagens são obviamente complementares. A mudança é estruturada e as estruturas mudam.

Burke (1980) orienta que, para compreender os distintos aspectos de uma determinada sociedade, precisamos trabalhar sempre na perspectiva da Sociologia e da História. Assim, "[...] não estabelecer fronteiras rígidas entre os campos sociológico e histórico permite que as categorias cumpram a função que lhes seja possível na construção do objeto" (MELO, 2014). E mais especificamente, no caso deste artigo, confrontar a Sociologia com a História da Educação delineia os matizes de nossa interpretação. Essas perspectivas teóricas e metodológicas permitem-nos compreender as respostas grafadas nos questionários e os sentidos dados pelos docentes ao contexto escolar da época.

De acordo com as indicações do historiador Roger Chartier as representações do mundo social são construídas, aspiram ser universais e estão ancoradas na razão. Contudo, o historiador nos afirma que elas "[...] são sempre determinadas pelos interesses de grupos que as forjam. Daí, para cada caso [há] o necessário relacionamento dos discursos proferidos com a posição de quem os utiliza" (CHARTIER, 2002, p. 17). Dessa forma, o autor argumenta que não existem discursos neutros, mas sim a produção de práticas e estratégias com tendências a coagir sua autoridade em detrimento de outras, autenticando ou justificando projetos formadores para os indivíduos e orientando suas escolhas e condutas.

As respostas concedidas pelos(as) professores(as) foram acionadas por uma memória construída no contexto da década de 1960, em um Estado marcado por profundas reformas nos campos da economia, da política e da educação, sobretudo devido à percepção da interdependência desses segmentos para a promoção da modernização. O discurso sobre modernização valorizou a atividade educacional como subsidiária da expansão econômica e "[...] como meio de promoção social do indivíduo e de aproveitamento da capacidade potencial da população" (LINS, 1999, p. 19). A ideia de planejamento ${ }^{3}$, nessa conjuntura, tornou-se um procedimento imprescindível. O desejado desenvolvimento de Santa Catarina seria alcançado, tão somente, se a sociedade fosse "convidada" a construir uma nova mentalidade, por meio da educação, para adequar-se ao perfil necessário a fim de trilhar os percursos rumo à modernização.

Optamos ao desenvolver este escrito por utilizar 173 questionários do total do acervo (820), tendo como recorte de trabalho a década de 1960. Destes, 24 são de homens e 
149 de mulheres. Priorizamos operar com dois itens: "Carreira profissional" e "Experiência pedagógica". Elegemos, no primeiro, a seguinte questão: Você foi filiado a alguma associação (religiosa, comunitária etc.), sindicato ou partido político? Quanto ao segundo item, analisar três questões foi fundamental para cumprir com o objetivo deste escrito:

a) Como era a relação entre sua escola e a igreja?

b) Fale sobre as aulas de religião (quem as ministrava e quais as suas finalidades)

c) Você vivenciou situações de discriminação (racial, sexual, origem social, religiosa) na sua escola?

Com essa seleção, empreendemos um esforço de interpretar as "falas" do professorado. As análises feitas buscaram compreender as filiações às quais professores e professoras foram associados(as); a relação entre escola e igreja; as aulas de religião e ainda as situações de discriminação. Com os(as) 173 professores(as) é que dialogamos, por meio de suas memórias marcadas nos questionários, para construir essa reflexão acerca das suas representações sobre religião e laicidade. Afirmamos que "[...] a explicação dessas representações/imagens traduz-se em testemunhos filtrados pelo tempo e pelas leituras que novas experiências provocam sobre a memória das vivências do passado" (MOGARRO, 2005, p. 13).

Quando responderam o que lhes foi solicitado, os(as) professores(as) não se limitaram unicamente a "dar respostas": foram além, objetando e ocupando os espaços em branco ociosos, as marginálias do questionário, incorporando elementos significativos que revelam "segredos" e memórias da profissão e do ser professor(a). Ao marcarem no papel suas escritas o professorado revelou e ocultou problemáticas da história da educação catarinense, brasileira e suas próprias histórias e memórias em uma "intrigante combinação entre a exaltação e o esquecimento" (NEVES, 2002, p. 5), partilhando conosco seus tesouros, enterrados nos mistérios de um tempo longínquo que os(as) cercava e envolvia, mas que, com solidariedade e generosidade nos permitem hoje escavar (MELO; VALLE, 2012, p. 199).

\section{QUANTIFICANDO A LEITURA DOS QUESTIONÁRIOS}

Ao trabalharmos a participação/filiação em alguma associação, seja religiosa, comunitária, sindical ou política, evidenciamos que os professores e as professoras da década de 1960 eram filiados a diversas associações. Dentre elas, destacamos: a religiosa $(26,75 \%)$, a comunitária $(10,19 \%)$, a política $(17,19 \%)$ e a sindical $(19,74 \%)$. Por outro aspecto, percebemos que $38,21 \%$ dos(as) professores(as) não eram filiados(as) a nenhuma agremiação; 8,9\% dos(as) professores(as) não responderam à questão e, ainda, outros(as) confirmaram a sua participação em associações sem, contudo, especificar qual frequentaram $(3,82 \%)$. 
${ }_{4}^{4}$ É certo que o autor analisa a situação do ensino religioso em cinco países tendo como foco o ano de 2005, marco do "centenário da lei de separação entre Igreja e Estado, na França" (CUNHA, 2006, p. 1236), mas tal estudo se projeta não unicamente pela importância da data nesse país, mas sim pela "relevância e atualidade do tema no contexto francês e mundial".
Quanto ao segundo item "Experiência pedagógica", analisamos as três questões anteriormente mencionadas. Na primeira: "como era a relação entre sua escola e a igreja" constatamos que $51,59 \%$ dos(as) docentes consideravam a relação entre essas instituições muito boa; 19,10\% consideravam-na excelente; $15,28 \%$, razoável; $1,91 \%$, péssima e $11,49 \%$ não responderam. Ainda tivemos a resposta de um professor que afirmou não haver relação entre a escola e a igreja (o,63\%). As relações interpretadas como muito boa e excelente se expressaram no que é pertinente à realização das atividades pedagógicas da/na escola, e dos festejos do calendário litúrgico na/da igreja. Isso revela que a igreja assumia, de certo modo, uma função no espaço escolar de apoiar pedagogicamente o professorado, o que, em tese, deveria ser de competência do Estado, mesclando laicidade com religiosidade. A escola por sua vez, servia como espaço para a disseminação dos dogmas da fé católica. Os testemunhos a seguir ratificam o apoio mútuo:

Sempre que a escola precisava fazer uma festinha, baile, o espaço da igreja ou o salão paroquial era cedido; os avisos da igreja eram repassados para os alunos (Professora Souza). Colaborava-se nas festas e promoções, inclusive cedendo as construções para o funcionamento da aula na igreja e da reza na escola (Professor Nelson).

Havia envolvimento com as celebrações, divulgação de realizações, os professores envolvidos com catequese (Professora Magarinos). Principalmente na parte da religião, onde as festas e comemorações eram feitas junto (Professora Benaci).

Diretoria de escola e igreja se entendiam muito bem. Igreja: sempre próxima da escola. O professor era chamado a tomar parte da igreja, sempre (Professora Jenfen).

A professora era o exemplo na escola e na igreja, pois funcionavam juntas (Professora Cinha). A escola participava em peso em celebrações religiosas; ensaiava cantos e instrumentais para apresentação na igreja. O pároco, a convite da escola, dava palestras sobre temas psicológicos e religiosos (Professora Kreuch Boing).

Ao observarmos esses testemunhos, coadunamos com os argumentos de Cunha $^{4}$ (2006, p. 1236), quando afirma que, no que diz respeito ao ensino religioso nas escolas públicas, a "derrota política dos setores laicos ativos" é um dos componentes que contribuíram para uma "[...] regressão do campo educacional, no que concerne à sua autonomização diante do campo político e do campo religioso". Além disso, o autor mostra que, em alguns estados brasileiros, como o Rio de Janeiro, "[...] ocorre um verdadeiro retrocesso no grau anteriormente alcançado, ou seja, os campos político, religioso e educacional tornam a se confundir, segundo padrões que lembram o Estado Novo". 
Assim, como revelam os testemunhos do professorado na década de 1960, observamos que a autonomia do campo educacional laico gozava (e ainda goza) de uma autonomia relativa em relação ao campo religioso. François Dubet, ao analisar o vínculo entre a cidadania e a escola francesa nota que, com relação

[...] à influência da Igreja sobre o espírito das crianças, era preciso opor a da escola pública, laica, gratuita e obrigatória. Era preciso que a herança do Iluminismo, da Razão, do Progresso e da Nação se sobrepusesse à da submissão à Igreja. No entanto, contrariando algumas ideias consagradas, esta escola da República não era antirreligiosa, sua moral era a da Igreja. (2011, p. 290).

Isso nos orienta a pensar que

[...] parece, de certa forma, que houve acordos entre o que o Estado impunha do alto, o que a sociedade esperava, as expectativas sociais do professorado e os anseios dos próprios professores. Contudo, isto não pode ser analisado sem se reconhecer, mesmo que não se possam identificar, que os supostos acordos são, muitas vezes, produto de longas disputas e tensões, objeto de resistência de uns e apreciados por outros. (GASPAR DA SILVA, 2004, p. 115).

Desta forma, o Estado, na década de 1960, ao objetivar - por meio da prática da pesquisa em educação - regular a profissão docente, "[...] aspirou à formação e organização de um corpo homogêneo, despido de diferenças e subjetividades, apto a desempenhar suas competências" (GASPAR DA SILVA, 2004, p. 115) modernizadoras, voltadas à busca de uma laicidade progressiva de Santa Catarina. Ao analisar tal processo em Portugal, Pintassilgo e Hansen (2011, p. 14) assinalam que "a secularização surgiu, [...] como um processo marcado por grandes ambiguidades". Essa afirmação está em conformidade com o que se percebia, também, em Santa Catarina nas décadas de 1960, uma vez que as "parcerias" estabelecidas com o campo religioso funcionaram como um obstáculo para a aquisição da autonomia nesse campo, considerando que elas possibilitaram que a religião hegemônica as tivesse como modo de subsidiar indiretamente o "Estado como instrumento de poder religioso e, consequentemente, político" (CUNHA, 2006, p. 1237).

A segunda questão: fale sobre as aulas de religião (quem as ministrava e quais as suas finalidades) trouxeram como indicações que os ministrantes das aulas de religião eram essencialmente os(as) professores(as) da classe, perfazendo um total de 56,19\%. As freiras foram mencionadas em um percentual de $3,18 \%$. Os(as) professores(as) 
remunerados(as) contratados(as) especialmente para tal função perfazem um total de $8,18 \%$, enquanto $0,63 \%$ declaram a presença de professores(as) voluntários(as). Os(as) professores(as) designados(as) pela direção para cumprirem a função representam 1,31\%. Além disso, foram apontados os padres como professores $3,80 \%$, como pastores $1,17 \%$ e como leigos $1,71 \%$. Um percentual de $23,20 \%$ não respondeu o questionamento. Somente um professor $(0,63 \%)$ foi categórico ao afirmar que não havia aulas de religião.

Os números nos mostram que, para a maioria dos(as) professores(as), o ensino religioso era parte integrante do currículo a ser por eles(as) desenvolvido, demonstrando que a questão entre a laicidade e a religião, "pode não ter a ver com autoridade e força, mas com experimentação", considerando que o professorado afirma ter sido "criado como católico" e que fala "a partir da religião" (LATOUR, 2004, p. 349). O mesmo sociólogo analisa que a religião "[...] não fala a respeito de ou sobre coisas, mas de dentro de ou a partir de coisas, entidades, agências, situações, substâncias, relações, experiências [...] que são altamente sensíveis aos modos como se fala delas" (LATOUR, 2004, p. 351).

Sou Católica-Praticante (Professora Filomena). Sou catequista, ministra da comunhão, ajudo minha comunidade (Professora Luciana).

Diácono da Igreja Católica (Professor Aiten). Católica, era catequista e fazia de padre (Professora Lunardi).

A maioria dos professores e alunos pertencia à religião predominante na cidade: católica (Professor Lehmbrhl).

Com tais afirmações, o professorado evidencia que dos "credos reconhecidos, para os quais [havia] aulas de ensino religioso" (CUNHA, 2006, p. 1241) figurava o cristão católico.

Cunha (2006), ao examinar o caso das cinco nações já citadas, observa que a religião, na França, quando relacionada com a escola pública, oscila na tensão entre fato religioso e vivência. Assim ele explicita:

[...] fato religioso é um objeto do conhecimento científico, portanto um fenômeno objetivamente observável, mediante o emprego do método científico. As religiões são, assim, apreendidas como fatos sociais, políticos, culturais, mentais e civilizatórios - históricos, o que quer dizer que são produto da vida humana em sociedade. (CUNHA, 2006, p. 1242).

Já para aqueles que a compreendem como vivência, ela "não deveria ser objeto de conhecimento" (CUNHA, 2006, p. 1242), e essa defesa provoca constantes tensões para os defensores do ensino laico nas escolas públicas. Podemos considerar, então, que a escola catarinense se 
distanciava daquilo que se propugnava para a escola republicana idealizada em berço francês: igualdade para todos, sem privilegiar nem rechaçar nenhuma crença pessoal.

A terceira questão colocada para os(as) professores(as) foi a seguinte: você vivenciou situações de discriminação (racial, sexual, origem social, religiosa) na sua escola? Dos 173 questionários analisados, 66,24\% do professorado argumentou que não vivenciou situação discriminatória de qualquer espécie, como pudemos observar em suas respostas:

Na época, aqui não tinha outra cor a não ser a branca: alemãs de origem (Professora Lohn). Tinha muito incentivo e preparo moral para respeitar o outro (Professora Pin);

Todas as crenças eram respeitadas (Professora Romanio).

Nunca houve essas situações (Professora Lijof). Não existia a discriminação escolar. Nós todos éramos iguais, tanto o pobre como o negro (Professora Mattos).

Não havia discriminação (Professora Figueredo).

Os alunos eram tratados todos iguais, respeitando sua origem, raça e religião (Professora Berneri).

Quando esse percentual de professoras e professores conclui que não sofreu processo discriminatório, não se percebe nessa situação, dando a entender que somente os seus alunos e alunas é que sofriam alguma discriminação. Em seus relatos, podemos observar questões importantes e que possivelmente tencionavam as relações naquele contexto, tais como as raciais (branco, negro), as econômicas (pobre) e as religiosas (crenças) como as mais recorrentes. O discurso da construção de valores que deveriam ser comuns são desmontados quando observamos que tais questões afligiam tanto os(as) alunos(as) quanto os(as) professores(as), como revelam a seguir:

Eu mesma fui discriminada porque tinha sardas e me chamavam de... Arroz doce/ferrugem/filha de mecânico (Professora Pedrozo). $\mathrm{Na}$ primeira formatura que participei aqui, um aluno negro (que nem tão negro era $\mathrm{e}$ tinha olhos verdes) foi impedido de participar do baile no clube onde havia a colação de grau, e ele tinha uma função na parte artística. Foi meu primeiro impasse. Não lembro como terminou. Discutíamos muito sobre isso na sala (Professora Boing).

Percebemos, então, nas falas que os discursos tendem a aparecer de maneira consensual e direcionada a uma ordem de tolerância e de liberdade, à busca de condições de igualdade dos alunos e alunas (e de si mesmos) independentemente de origem. A escola desponta como uma 
espécie de "substituta dos púlpitos", nos quais a ordem do discurso era "[...] alcançar a ascensão social como mecanismo de poder por meio do qual se poderia inculcar os princípios [...] as novas gerações, garantindo a consolidação da ordem" (NETO, 2010, p. 202). Como afirma Cunha (2006) em seu estudo, a palavra de ordem que funcionava como amenizadora das tensões era "temperança". Contrariando as afirmações dos professores e das professoras que disseram não existir discriminação, $17,83 \%$ revelam que presenciaram pelo menos uma situação desse caráter. Entre as respostas obtidas, algumas chamaram a atenção:

Algumas, mas sem importância (Professora Benaci).

Era de forma velada (Professora Schmitt).

Havia, sim. Era comum na época (Professora Schafer).

Entre alunos, por aprendizagem, por situação financeira; mas, era a minoria (Professora Gonzaga).

Essas respostas induzem-nos a crer que existia um paradoxo "[...] responsável pelo acúmulo de tensões culturais e políticas [e religiosas] no sistema público de educação": uma parcela do professorado minimiza a situação de discriminação, mostrando que o "catolicismo foi-se mantendo como referência ideológica e como fator de consenso social" (PINTASSILGO, 2011, p. 8). Pintassilgo, ao desenvolver estudos sobre a laicidade, religiões e educação na Europa do Sul no Século XX, argumenta que posicionamentos como os descritos anteriormente já vinham sendo questionados "[...] de forma radical, pelos movimentos republicanos e laicos que se desenvolvem, entre o final do século XIX e as primeiras décadas do século XX", e que assumem como uma das suas principais metas a laicização da sociedade e da escola (PINTASSILGO, 2011, p. 8). Contudo, para o mesmo autor, as "[...] tendências secularizadoras [...] não obstaram à presença de manifestações de sentido contrário, ainda que só na aparência” (PINTASSILGO, 2011, p. 14).

É importante anotar, também. que outro contingente mostra, por meio da denúncia, estar preocupado em "oferecer um espaço laico e livre para o encontro de tradições religiosas diferentes" (CUNHA, 2006, p. 1246), indicando que "[...] a escola passa a ser, nesses momentos, o lugar ideal para a formação do novo cidadão republicano, laico e patriota e já não do homem católico e temente a Deus" (PINTASSILGO, 2011, p. 8).

Ao constatarmos que $15,93 \%$ do professorado não respondeu à pergunta sobre discriminação e que $66,24 \%$ afirma a sua não existência, compreendemos que essa temática emergia como uma espécie de tabu ou talvez estivesse ausente a sensibilidade ou a percepção que se tem hoje, tema sobre o qual não se discutia devido, provavelmente, à ideia de uma sociedade harmoniosa - 
${ }^{4}$ A grafia da palavra foi mantida do original.

\footnotetext{
5 Disponível em: <http://www.galizalaica. net/2014/o2/glossario-da-laicidadeadaptado-do-livro-lavenir-laique-deetienne-pion-por-luis-m-mateus/>.
}

especialmente a partir do ano de 1964, quando ocorreu no Brasil a mudança de regime governamental, no qual prevalecia a ordem visando ao progresso. Nesse período, foi traçada para o País "uma rota na direção da laicização da sociedade" (CUNHA, 2006, p. 1247). Assim, o campo religioso passou a "a ser visto, [...] como uma dimensão possível da vivência humana e menos como um campo de combate" (PINTASSILGO, 2011, p. 8).

\section{A RELIGIÃO E A LAICIDADE: "O FUNCIONAMENTO DA AULA NA IGREJA E DA REZA NA ESCOLA"}

Memória

"Amar o perdido deixa confundido este coração. Nada pode o olvido contra o sem sentido apelo do Não. As coisas tangíveis tornam-se insensíveis à palma da mão. Mas as coisas findas, muito mais que lindas, essas ficarão".

Carlos Drummond de Andrade

A ideia de entretecer relações entre laicidade, religião e educação possui, segundo Pintassilgo: “[...] uma história rica e multifacetada, mas também de grande atualidade e, ainda hoje, passível de alguma polêmica" $\left(2011\right.$, p. 7) ${ }^{4}$. Para esse autor,

[...] a educação foi proporcionada, em muitos momentos da história da humanidade, em contextos religiosos, envolvendo atores a eles associados e com conteúdos permeados por valores igualmente religiosos. Os processos de secularização que se afirmaram sob o influxo do iluminismo e, em particular, a assunção, por parte dos Estados, da responsabilidade de criação de sistemas públicos de ensino veio pôr em causa o tradicional papel da Igreja Católica neste terreno. (PINTASSILGO, 2011, p. 7).

A responsabilidade dos estados nacionais pela oferta de educação coloca na pauta de discussões a ideia de secularização, que se manifesta na escola por meio da ideia de laicidade. Dessa maneira, é relevante explicitar o entendimento dos termos, laico, leigo e laicidade. Luís M. Mateus ${ }^{5}$ fundamentado no livro L'avenir laique, de Étienne Pion clarifica: laico, no francês laique, deriva da palavra grega laikos, isto é, "que pertence ao povo". Na tradição romana, laicus possui o mesmo sentido equivalente. Cunha (2013, p. 9), ao analisar o termo "laico", o faz em referência ao Estado, que deve ser "[...] imparcial diante das disputas do campo religioso, que se priva de interferir nele, seja pelo apoio, seja pelo bloqueio a alguma confissão religiosa".

Já o termo leigo, laic na língua francesa, segundo Cunha (2013, p. 32), é usado pela Igreja Católica para 
${ }^{6}$ Cunha (2013, p. 9) exemplifica: no que diz respeito à educação, o professor leigo é aquele que leciona, mas não dispõe de um curso de formação específica para o exercício da função (normal, magistério, licenciatura), isto é, não recebeu a necessária "certificação da burocracia, que exerce seu poder em cada campo". designar os católicos não membros do clero, mas que exercem responsabilidades menores ou marginais no seio da comunidade religiosa. Sobre o termo leigo, esse autor esclarece que: "[...] não concerne ao Estado nem a uma instituição, mas a um indivíduo ou grupo de indivíduos que não dispõe de determinada formação, tomada como referência"6 (p. 9). O termo laicidade, laicité no francês, pode ser considerado sob dois aspectos: como ética e estatuto cívico. No que diz respeito ao primeiro aspecto, a laicidade pode ser compreendida como um conjunto de valores usados tanto individual, quanto coletivamente.

Étíenne Pion define a laicidade como "um conjunto de valores e ao mesmo tempo um sistema de vida social e cívica" ([s. d.], p. 1-2). Esses valores são caracterizados como liberdade de consciência de crer ou não em um Deus. Para ele, os indivíduos laicos se fundam na razão como reflexão livre. Dessa forma, o autor relaciona laicidade a outros conceitos e princípios, tais como tolerância e, por essa razão, prefere definir laicidade como um sistema que "respeita as diferenças", que gera uma atitude favorável à vida coletiva. E o termo laico é interpretado como uma postura frente à vida e a diferentes dogmas. Para Pion,

[...] os laicos são a-dogmáticos. Este pressuposto aplica-se a todo o tipo de dogmas: religiosos, políticos, culturais, e até econômicos. A recusa da verdade dogmática em qualquer domínio não invalida a existência de critérios de referência, até porque estes são sempre necessários. Para os laicos, esses critérios fundam-se na Razão. A Razão como instrumento da reflexão livre. O que não significa que recusem outras formas de pensamento, assentes na sensibilidade, na intuição ou na imaginação. Estas formas são adaptáveis à razão. $\mathrm{O}$ que o laico defende é o rigor nas reflexões e abertura no pensamento. (([s. d.], p. 2).

Cunha (2013, p. 10) assinala que a laicidade não “[... ] está pronta e acabada em lugar nenhum do mundo. Ela é um processo", uma vez que é uma construção histórica, sempre em busca de aproximação.

No que se refere à laicidade, no Brasil, podemos argumentar que floresce com o advento da república, como marco. É neste período que, de acordo com as análises de Emerson Giumbelli é adotado, de maneira assumida,

[...] o princípio da separação entre Estado e igrejas. [...] rompe-se com o arranjo que oficializava e mantinha a Igreja Católica; o ensino é declarado leigo, os registros civis deixam de ser eclesiásticos, o casamento torna-se civil, os cemitérios são secularizados; ao mesmo tempo, incorporam-se os princípios da liberdade religiosa e da igualdade dos grupos confessionais, o que daria legitimidade ao pluralismo espiritual. (GIUMBELLI, 2008, p. 81-82). 
Então, a laicidade corresponde a um arranjo político, no qual a liberdade de consciência se encontra e onde, em tese, a justiça deveria ser igual para todos. A laicidade é composta por quatro elementos, a saber: a liberdade de consciência, a igualdade entre convicções religiosas e filosóficas, a neutralidade estatal e a autonomia do político (GIUMBELLI, 2008). Fábio Carvalho Leite (2011, p. 37), declara que, "[...] embora a República tenha trazido consigo a separação entre Estado e religião, a verdade é que a laicidade e a liberdade religiosa têm uma história própria, autônoma, que não necessariamente se relaciona com a trajetória da causa republicana" . Nesse aspecto Cunha (2013), mais uma vez, contribui para o entendimento. Para ele, o processo de laicização do Estado brasileiro teve início ainda no Império, com a "luta pela liberdade religiosa num Estado confessional católico” (p. 11); continuou na República, com a cisão na qual ocorreu a abolição dos privilégios da religião hegemônica, seguindo com a reinvindicação da imparcialidade do estado diante do campo religioso.

Em seus estudos sobre a laicização da sociedade brasileira, Wenceslau Gonçalves Neto (2010) afirma que houve um "ajuste" entre a Igreja e o Estado que interessava e beneficiava a ambos. Assim, o Estado garantia "[...] o apoio de um setor com grande penetração numa sociedade maciçamente católica, e a Igreja garantia rendas e acesso ao poder por conta dos serviços que passou a prestar ao Estado, como controle de nascimento, casamentos, óbitos eleições" (NETTO, 2010, p. 200).

Considerar os pilares que sustentam a história do campo religioso no campo educacional implica qualificar a laicização, que é por nós interpretada como parte integrante de um processo de modernização do estado brasileiro. Como um vetor do processo de modernização, procura erguer-se a formação de professores(as) sobre o paradigma da modernização, ou seja, procura-se desenhar o perfil de um professor fundamentado na laicidade, deslocado da moral religiosa.

No modelo de sociedade modernizada, representada em máxima instância pelo advento da República, não caberia um "problema" como a composição de um corpo docente formado em sua maioria esmagadora por professores(as) leigos(as) e intrinsecamente religiosos(as). Aguiar (2004, p. 9) analisa a complexidade deste fenômeno e entende que "[...] enfrentar essa questão implica repensar o conjunto da política educativa do país bem como o compromisso das elites com a educação básica; o papel que esta deve desempenhar em uma sociedade democrática; o perfil e a formação [...]” do(a) professor(a) do primário. Esse autor entende que a República herdou

[...] uma instrução pública (ensino primário) deficiente e disforme, com um corpo docente de quase $80 \%$ de leigos/as, mal preparados, que adquiriram seus diplomas em bancas 
de exames de suficiência, realizados sazonalmente e sem rigor para ministrarem uma educação propedêutica, predominantemente livresca e com pouca atenção aos estudos das ciências. (AGUIAR, 2007, p. 16).

Nóvoa (1999) assevera que o processo de profissionalização do professor é histórico e inscrito na busca de laicizar e estatizar, visando a um processo de educar mais controlado. As maneiras de produzir e de se reproduzir a "visão de mundo" sofrem, desse modo, uma vigilância mais rigorosa. Esse processo se consistiu, especialmente, mediante a "[...] substituição de um corpo de professores religiosos (ou sob o controle da Igreja) por um corpo de professores laicos (ou sob o controle do Estado), sem que, no entanto, tenham ocorrido havido mudanças significativas nas motivações, nas normas e nos valores originais da profissão docente" (NÓVOA, 1999, p. 15). As reflexões de Nóvoa associadas às de Giumbelli tornam explícito que "[...] certas formas de presença da religião no espaço público não foram construídas por oposição [...] mas, por assim dizer, no seu interior" (GIUMBELLI, 2008, p. 80-81).

Ainda que o Estado, em tese, estivesse comprometido com os princípios da laicidade, em seu interior ocorreu um forte comprometimento moral construído sob os pilares da base religiosa católica, o que permite inferir que houve uma abdicação da sua função socializadora, que foi cedida às instituições religiosas (CUNHA, 2013). Cavalieri argumenta:

[...] uma vez que propostas laicas e democráticas do próprio campo educacional, por motivos variados, não foram implantadas ou não se consolidaram no ambiente escolar, $o$ Ensino Religioso de caráter dogmático-confessional [...] passa a ocupar-se destas tarefas e a encaminhar a seu modo concepções e propostas para a socialização global dos alunos. (CAVALIERI, 2006, p. 4).

A professora Assis demonstrou que compreendia a fragilidade do Estado laico, fazendo as seguintes afirmações:

[...] o Brasil é reconhecido como país laico. No entanto, em toda sala de aula, repartição pública há o símbolo de uma só religião. Atualmente os pais mais esclarecidos, exigem o respeito pelas suas crenças. $\mathrm{O}$ uso de símbolos impõe uma religião, uma igreja; o laicismo não era respeitado. O professor de classe ministrava as aulas sempre de uma só religião;

Uma aluna ( $3^{\mathrm{a}}$ série) pediu a sua professora para retirar-se da sala, por orientação dos pais, quando da aula de religião contrária à sua fé. Grosseira, a professora disse para a aluna sentar-se no banco do corredor e aguardar. A diretora da época exigiu que, mesmo 
chorando, a aluna entrasse e escutasse a aula. Pura violência no Brasil "laico". Comprei a "briga"; ganhei um desafeto (a diretora).

As memórias da professora Assis sobre a laicidade na educação escolar permitem-nos inferir que havia o predomínio de uma crença religiosa - "a fé católica" - em detrimento de outras crenças devido a uma presença recorrente no currículo da escola das questões morais fundamentadas no catolicismo. Dessa maneira, conforme defende Cunha (2013, p. 11), esclarecemos que não há "uma linha contínua, pois há contradições que ficam atenuadas ou são acirradas", mostrando que "existem recuos e avanços no percurso de construção da laicidade do Estado". Esse autor ainda adverte que

[...] o fortalecimento da presença da religião na escola pública vem na exata medida em que a ação educativa escolar enfraquece. Revela, de um lado, a capitulação do Estado e, de outro, o fracasso do sistema educacional em uma ação mais efetiva no processo de socialização e de incorporação social das grandes massas da população. (CUNHA, 2013, p. 25-26).

Entre os avanços e recuos da laicidade no campo educacional, pode estar uma possível explicação para o fato de determinados(as) professores(as) perceberem a hegemonia da fé católica e sua presença na escola de maneira naturalizada e como apaziguadora de eventuais confrontações de qualquer ordem. Afirmam que:

Os mesmos pais, os mesmos alunos na mesma igreja e escola (Professor Fagundes).

Em primeiro lugar, eram todos católicos, isso era um bom caminho para uma boa relação (Professora Dorvalina).

A minha comunidade era maioria católica (Professora Gonçalves).

Só havia praticamente uma religião a seguir; então, todos eram católicos. E havia bom entrosamento neste sentido (Professora Rossato). Havia muito bom entendimento (Professora Iolanda).

Assim, a questão do ensino público parece, ainda, ser reputada a um sacerdócio, no qual se exige dos(as) professores(as) "mais dedicação e abnegação do que preparo científico" (AGUIAR, 2007, p. 15), o que, na leitura de Cunha (2013, p. 11), significa "a colonização religiosa da escola pública". Sobre a relação entre a função docente e o sacerdócio, Dubet (2011, p. 294) contribui para compreendermos que zado em nome de princípios transcendentes, 
sagrados, é evidente que o profissional que realiza esse trabalho é definido por sua vocação. Nesse contexto, a vocação é menos uma disposição psicológica do que a identificação aos princípios que fundam a instituição.

Para o mesmo teórico: assim como o padre acredita nos dogmas da Igreja, o(a) professor(a) precisa acreditar nos valores da escola republicana (DUBET, 2011). Assim, ambos, tanto o padre, quanto o(a) professor(a) são figuras elevadas ao patamar do sagrado. E este último precisava ser recrutado e ser formado segundo o "credo" do Estado laico. Nesses termos,

[...] a vocação ocupa um lugar essencial no dispositivo do programa institucional. Ela funda a legitimidade e a autoridade daquele que trabalha com outrem e que por isso se beneficia, por delegação, de um pouco de carisma porque representa algo de superior a todos. Assim como o padre porta uma parte do divino, o professor primário encarna um pouco da República, da Razão, da grande cultura. (DUBET, 2011, p. 294).

A professora Dias apresenta uma percepção mais ampla sobre essa questão, ao perceber que o domínio da confissão católica se estendia para além da esfera educacional, revelando-se, também, no setor político. Ela argumenta:

Na verdade, apenas recordo que havia espaço na escola somente a católicos. Somente na década de 1980-1990, pastores luteranos tiveram espaço, mas era pequeno. Na verdade, no meu "achismo", a escola não tinha (dispunha) de conhecimento, clareza, disposição e vontade para abrir esse leque. O que também ocorria em relação às autoridades.

A fala da professora Dias reitera a tradição longeva, exclusiva e monopolista da Confissão Católica na educação brasileira, ratificando que "a escola era uma arena de disputa religiosa" (CUNHA, 2013, p. 22). A parceria entre Igreja e escola primária catarinense acorreu das mais distintas formas: na ministração e difusão dos dogmas da religião católica na escola por meio da catequese; na cooptação de professores para atuar como ministros, capelães e apóstolos; nas festividades comunitárias e nas pastorais. As falas, a seguir, revelam a participação dos(as) professores(as) como reforçadores(as) das relações entre a escola (como instituição ligada ao Estado) e a Igreja:

Era ligado à igreja, dava palestras e cursos (Professor Lehmbrhl).

Apostolado da oração - Ministro da Eucaristia (Professor Fagundes).

Apostolado da oração - a professora dava catequese, fazia leitura na missa e iniciava os 
7 Weiss fez a apresentação e tradução de "O ensino da moral na escola primária", conferência de Durkheim que sintetiza sua proposta de uma educação moral de fundamento laico, que ficou inédita na França durante mais de 80 anos e foi publicada pela primeira vez em português. cantos, além de preparar as vestes do sacerdote para a missa (Professora Regatto).

Pastoral da criança (Professora Padilha).

Pastoral da criança e da saúde (Professora Oliveira).

Sou ministra da palavra e catequista em minha igreja (Professora Guilhermina),

Apostolado da oração e Legião de Maria (Professora Miotto).

A escola e a igreja caminhavam juntas, ensinando o bem a todos (Professor Guützmacher). Padres de religiosos vinham à escola e a escola ia à igreja (Professora Ribeiro).

$O$ professor era o catequista e, às vezes, o capelão (Professora Bonetti).

Assim, de um lado, parte do corpo docente existente em Santa Catarina no período de 1960, parecia estar profundamente arraigado na formação que (con)funde o sacerdócio laico e o religioso, pois exercia um papel social importante, atuando na divulgação do conhecimento oriundo da razão e de dogmas religiosos, não unicamente na escola, ao disseminar as doutrinas católicas, mas também na igreja, ao exercer funções de apoio às práticas clericais.

O trabalho colaborativo objetivava a formação de valores morais para além da educação moral e laica. A religião desponta como uma referência social na construção desses princípios morais que, de acordo com o que os(as) professores(as) pretendiam:

Saber da existência de um superior: Deus. Ensinar que Ele tudo pode e devemos colocá-lo no coração (Professora Silveira).

Ensinar o amor a Deus e aos irmãos, rezar e conhecer algumas passagens da bíblia (Professora Benaci).

Um conhecimento de um ser superior, a prática do amor, caridade (Professora Abisi).

Procuravam dar uma formação moral e religiosa (Professora Sardá);

Deus o criador. Natureza, homem, animais, amor, perdão, amigos, partilha, etc (Professor Minich).

Religião pode ser introduzido em qualquer disciplina. Não existe ciência ou geografia sem se falar de Deus (Professora Lohn).

Falava-se no criador de modo geral, enfocava-se também a moral e o civismo (Professora Romanio).

Objetivando a conscientização e valorização da vida (Professora Sehnam).

Contudo, de acordo com Raquel Weiss 7 , “[...] não seria suficiente realizar um ensino leigo da moral, mas seria imprescindível o ensino de uma moral laica” (DURKHEIM, 2007 , p. 61), objetivo que certos(as) professores(as) pretendiam atingir, mas nem sempre tinham êxito. Sobre o mesmo problema Émile Durkheim (2007, p. 62) vai além, afirmando que "[...] é necessário um método conveniente 
para o ensino da moral laica" e que "as doutrinas metafísicas [...], não são acessíveis às crianças" (2007, p. 62). O sociólogo adverte sobre a necessidade de cumprir tal tarefa com êxito:

[...] para que estejamos autorizados a prescindir das religiões, é preciso que tenhamos razões suficientes para crer que podemos cumprir essa tarefa melhor ou tão bem quanto elas. É necessário que tenhamos motivos para acreditar que somos capazes de prestar os mesmos serviços e, por conseguinte, nossa primeira preocupação deve ser buscar quais são os serviços que as religiões têm prestado, de modo que possamos perceber se estamos em condições de satisfazer às mesmas necessidades, mesmo que de outra maneira. (DURKHEIM, 2007, p. 62).

É preciso, de acordo com Durkheim, desfazer os nós que atam a moral à religião. Weiss - inspirada nas ideias durkheimianas sobre a moral laica - acentua que, para o sociólogo, a “[...] verdadeira origem de Deus não é outra senão a sociedade, o que lhe permitiu mostrar, ao mesmo tempo, a origem humana da divindade e o caráter sagrado que se atribui à moralidade", ou seja, uma moral laica deve fundar-se na natureza das coisas (DURKHEIM, 2007, p. 61).

Os(as) professores(as) catarinenses buscavam cultivar uma moral que parece se encontrar fora do mundo social, mas que, ao mesmo tempo, serve como fio que urde a trama social; porém, Weiss comenta que o pressuposto de uma educação puramente laica se pauta em "[...] uma educação racional, que revela a origem social da moralidade, [como] a única que pode forjar nos indivíduos aquilo a que [Durkheim] chamou de "espírito de autonomia" (DURKHEIM, 2007, p. 61). O sociólogo Émile Durkheim (2007, p. 62) argumenta que "[...] é possível ensinar a moral sem se apoiar em nenhuma espécie de religião revelada, tampouco em qualquer teologia racional", contrariando a ideia de que os princípios morais pautados na religião sejam essenciais.

Por outro aspecto, o princípio de colaboração, de aproximação, esteve fundado e subordinado ao princípio da separação. Essa ideia de distanciamento entre as instâncias do Estado e da religião habitam o imaginário de determinado(as) professores(as), que de modo contundente afirmam a laicidade da educação escolar catarinense:

No início, separava as aulas de acordo com as crenças; depois, mandava sair da sala de aula (Professora Tárcila).

Os professores seguiam um manual de educação religiosa enviado pelo Estado (Professora Dias).

Havia respeito a todas as crenças (Professora Pin Oss-emer). 
Ficava distante uma da outra e, poucas vezes, lembro-me de ter acontecido eventos religiosos envolvendo escola e igreja (Professora Farias).

Alguns profissionais com preparo trabalhando o ecumenismo. Muito boas. Outros, a desejar, se detinham mais na religião (Professora Westerisch Bom).

Sob essa perspectiva de colaboração, Pintassilgo e Hansen (2013, p. 15) argumentam:

[...] fazendo algum balanço, podemos adiantar que a unidade moral e espiritual pretendida [...] resulta da conjugação dos princípios liberais e dos valores tradicionais do catolicismo, duas heranças que não são vistas como antagônicas, antes pelo contrário.

Assim, em muitas falas, percebemos que a questão da laicidade está relacionada ao princípio da liberdade de religião ou à abordagem ecumênica no interior da escola, e não propriamente na extinção da "aula de religião" do currículo escolar em detrimento de uma proposta de educação moral de fundamento laico. Laicidade na compreensão dos(as) professores(as) seria:

Ministrava as aulas, mas nunca impondo uma determinada religião (Professora Silva). As aulas de religião são ministradas em nível ecumênico e bem aceitas (Professor Aiten). [As aulas] eram ministradas pela professora da turma. Não enfocava nenhuma religião. Falava-se no criador de modo geral. Enfocava-se, também, a moral e o civismo (Professora Romanio).

No que é pertinente à educação laica, Weiss explica que Durkheim deixa sua contribuição em um dos aspectos mais importantes que "é aquele que contempla o conjunto de suas proposições normativas", para a concretização dessa educação, que "[...] transcende os limites da positividade científica, uma vez que avança também no terreno normativo" (DURKHEIM, 2007, p. 60).

Tendo em vista que os(as) professores(as) catarinenses estabelecem uma relação direta entre laicidade, ecumenismo e liberdade religiosa, Rocha (2010, p. 7) recomenda compreender que a democracia e a laicidade, estão "intrinsecamente ligadas e fortemente presentes no direito à liberdade religiosa" e que "a laicidade é baseada na soberania dos cidadãos, livres e iguais”. Desse modo, Giumbelli (2008, p. 82) destaca que "a mesma Igreja Católica que foi contra a separação se colocou a favor da liberdade", considerando que era um direito outorgado pela Constituição de 1891.

O processo de laicização implica a exclusão do ensino religioso na escola pública e não na inserção de abordagens ecumênicas e/ou liberdade religiosa em seu interior. 
De acordo com Neto (2010, p. 205), esse processo se define quando ocorre "[...] a decisão do Estado de formar um sistema próprio de difusão da cultura e da ideologia, implementando um sistema nacional de ensino", antes disso, minado por "grande parte do antigo poder da igreja". Assim, laicização denota não a substituição do conteúdo religioso, mas sim a sua supressão das escolas públicas.

\section{CONSIDERAÇÕES FINAIS}

A intenção deste estudo foi o de estabelecer e constituir um espaço de reflexão sobre laicidade e religião na compreensão de professores(as) do primário do Estado de Santa Catarina na década de 1960, para fazer aflorar informações e interpretações novas sobre os fenômenos históricos que os cercam e, também, relacioná-los às formas educativas, desenvolvidas a partir das implicações e relações com o Estado, a sociedade e a religião.

As reflexões sobre a religião e a laicidade nos revelaram, por meio das memórias dos(as) professores(as) primários(as) de Santa Catarina, as vivências e as relações que eles(as) mantinham com a religião na década de 1960. A Igreja, em certos períodos da história, tinha grandes poderes - econômico, político e social - e exercia uma forte influência sobre a escola. Considerando que a religião que mais predominava na década de 1960 era a católica, as outras pouco eram evocadas pelos(as) professores(as).

Os(as) professores(as) com os(as) quais interagimos por meio dos questionários viveram próximos aos "primórdios da profissão docente no Brasil”, em uma sociedade que se transformava e na qual a questão educacional também se modificava, passando de um processo que se dava por impregnação da cultura dominante, para a complexificação social, onde o Estado assume a responsabilidade pela modernização e "formação do povo". O Estado, ao assumir o papel e a responsabilidade de modernizador, formador do povo e laicizador não deveria intervir no modo como cada indivíduo pensava acerca da religião. Caberia a cada cidadão fazer suas próprias escolhas, mas sempre respeitando e sem afligir as leis estabelecidas pelo Estado. Contudo, nas escolas públicas prevalecia uma só fé, um só credo: o católico romano. A laicidade era compreendida ou associada pelos(as) professores(as), catarinenses como ecumenismo ou liberdade religiosa e não como um processo de retirada dos currículos escolares do estudo dos conteúdos religiosos.

Esses conteúdos, segundo os(as) professores(as), contribuíam para a constituição da moral individual e social, considerando que, por meio daqueles, eram desenvolvidos princípios morais subjetivos como o amor a Deus e aos irmãos e objetivos como o bom relacionamento, a natureza, o homem, os animais, a justiça, o direito e, até mesmo, como um mecanismo para cumprir a finalidade de complemento curricular, pois "[...] quando faltavam algumas 
aulas para completar a carga horária, eram preenchidas com essa disciplina" como expressa a professora Kreuch Boing.

Nossos estudos vêm demostrando que a presença da religião, sobretudo católica, e os estudos religiosos no cotidiano da escola laica, gratuita e obrigatória atravessa a segunda metade do século XX e permanece forte até os dias de hoje. Focamos, então, a presença da religião e os primeiros vestígios da laicidade na educação básica catarinense, além de possíveis confrontos das duas vertentes entre o professorado. De acordo com as falas de alguns(mas) professores(as) do primário, a laicidade manifestava seus primeiros vestígios, sendo ela entendida como um conjunto de valores, que respeitam a liberdade absoluta da consciência e também a liberdade de expressão.

\section{REFERÊNCIAS}

AGUIAR, Ranieri Roberth Silva de. A construção histórica e política do professor/a leigo/a no Brasil: um estudo de caso sobre o proformação. $2007.78 \mathrm{f}$. Dissertação (Mestrado em Teologia) - Programa de pós-graduação em Teologia, Escola superior de teologia, Faculdades EST, São Leopoldo, 2007.

AMORIM, Maria das Dores Daros de. Plano Estadual de Educação: concretização das orientações políticas da educação. 1984. 148 f. Dissertação (Mestrado em Sociologia) - Programa de Pós-Graduação em Ciências sociais, Universidade Federal de Santa Catarina, Florianópolis, 1984. Disponível em: <http://docplayer.com.br/15632534-Universidade-federal-de-santa-catarina-departamento-de-ciencias-sociais-programa-de-pos-graduacao-em-ciencias-sociais.html>. Acesso: 11 abr. 2013.

BURKE, Peter. Sociologia e História. 2. ed. Porto: Edições Afrontamento, 1980.

CAVALIERI, Ana Maria. Quando o Estado pede socorro à religião. Revista Contemporânea de Educação, Rio de Janeiro, v. 1, n. 2, p. 1-12, jul./dez. 2006.

CHARTIER, Roger. A História Cultural: entre práticas e representações. 2. ed. Lisboa: Difel, 2002. (Coleção Memória e Sociedade).

CUNHA, Luiz Antônio. Ensino religioso nas escolas públicas: a propósito de um seminário internacional. Educação \& Sociedade, Campinas, v. 27, n. 97, p. 1235-1256, set./ dez. 2006. Disponível em: <http://www.scielo.br/pdf/es/ v27n97/ao8v2797.pdf>. Acesso: 12 abr. 2013.

DUBET, François. Mutações cruzadas: a cidadania e a escola. Revista Brasileira de Educação, v. 16, n. 47, p. 289-305, maio/ago. 2011. 
DURKHEIM, Émile. O ensino da moral na escola primária. Apresentação e tradução de Raquel Weiss. Novos Estudos - CEBRAP [online], n. 78, p. 59-75, 2007. Disponível em: <http://www.scielo.br/scielo.php?script=sci_ arttext\&pid=S0101-33002007000200008\&lng=pt\&nrm= iso\&tlng=pt>. Acesso em: 20 set. 2012.

GASPAR DA SILVA, Vera Lucia. Sentidos da profissão docente. Estudo comparado acerca de sentidos da profissão docente do ensino primário, envolvendo Santa Catarina, São Paulo e Portugal na virada do século XIX para o século XX. Tese de Doutorado. Faculdade de Educação da Universidade de São Paulo. 2004.

GIUMBELLI, Emerson. A presença do religioso no espaço público: modalidades no Brasil. Religião e Sociedade, Rio de Janeiro, v. 28, n. 2, p. 80-101, 2008.

GLOSSÁRIO da Laicidade - Adaptado do livro L'AVENIR LAIQUE de Étienne PION por Luis M. Mateus. 2014. Galiza Laica. Disponível em: <http://www.galizalaica. net/2014/o2/glossario-da-laicidade-adaptado-do-livro-lavenir-laique-de-etienne-pion-por-luis-m-mateus/>. Acesso em: 12 jun. 2015.

LATOUR, Bruno. Não congelarás a imagem, ou: como não desentender o debate ciência-religião. Revista Mana, v. 10, n. 2, p. 349-376, 2004.

LEITE, Fábio Carvalho. O laicismo e outros exageros sobre a Primeira República no Brasil. Revista Religião e Sociedade, Rio de Janeiro, v. 31, n. 1, p. 32-60, 2011.

LINS, Zenilda Nunes. Faculdade de Educação: projeto e realidade. 2. ed. ampl. e atual. Florianópolis: UDESC, 1999.

MELO, Osvaldo Ferreira de. UDESC: 25 anos de uma estratégia modernizadora. In: Idealização e construção da história - UDESC 1965-1990: Universidade Federal da Santa Catarina. Florianópolis: UDESC, 1990. p.?

MELO, Marilândes Mól Ribeiro de; VALLE, Ione Ribeiro. Professoras catarinenses: razões para escolher e permanecer na carreira. Revista Brasileira de Educação, Campinas, v. 12, n. 3, 199-228, set./dez. 2012. (no prelo).

MELO, Marilândes Mól Ribeiro de. "Não sei se valeu à pena ter sido professor, mas foi uma vida": convergências e divergências entre o projeto de modernização do governo catarinense e o corpo docente da Rede Estadual de Ensino de Santa Catarina (Década de 1960). 2014. 391 f. Tese (Doutorado em Educação) - Programa de Pós-Graduação em Educação, Centro de Ciências da Educação da Universidade Federal de Santa Catarina, Florianópolis, 2014. Disponível em: <https://repositorio. ufsc.br/bitstream/handle/123456789/129377/329780. pdf?sequence=1>. Acesso em: 13 jun. 2015. 
MELO, Marilândes Mól Ribeiro de; VALLE, Ione Ribeiro. Professoras catarinenses: razões para escolher e permanecer na carreira. Rev. bras. hist. educ., Campinas, v. 12, n. 30, p. 197-226, set./dez, 2012 (no prelo).

MOGARRO, Maria João. Memórias de Professores: discursos orais sobre a formação e a profissão. História da Educação, Pelotas, n. 17, p. 7-31, abr. 2005.

NETO, Wenceslau Gonçalves. A secularização da sociedade brasileira. In: CARVÁLHO, Carlos Henrique de; NETO, Wenceslau Gonçalves. Estado, Igreja e Educação: o mundo ibero-americano nos séculos XIX e XX. Campinas: Editora Alínea, 2010. p. 99-222.

NEVES, Margarida de Souza. Apresentação. In: Mignot, Ana Chrystina Venancio. Baú de memórias, bastidores de histórias: o legado pioneiro de Armanda Álvaro Alberto. Bragança Paulista: EdUSF, 2002. p. 5-9.

NÓVOA, António. O Passado e o Presente dos Professores. In: NÓVOA, António (Org.). Profissão Professor. Porto: Porto Editora, 1999. p. 9-32.

PINTASSILGO, António Joaquim de Souza. História da Formação de professores. Relatório sobre os conteúdos, métodos de ensino e bibliografia da disciplina Historia da Formação de Professores. Universidade de Lisboa. Instituto de educação. Lisboa, 2011.

PINTASSILGO, António Joaquim de Souza. Introdução. In: PINTASSILGO, António Joaquim de Souza. (Coord.). Laicidade, Religiões e Educação na Europa do Sul no Século XX. 1. ed. Lisboa: Instituto de Educação da Universidade de Lisboa, jun. 2013. (Coleção Encontros de Educação).

PINTASSILGO, António Joaquim de Souza; HANSEN, Patricia. A laicização da sociedade e da escola em Portugal: um olhar sobre o século XX. In: PINTASSILGO, António Joaquim de Souza. (Coord.). Laicidade, Religiões e Educação na Europa do Sul no Século XX. 1. ed. Lisboa: Instituto de Educação da Universidade de Lisboa, jun. 2013. p. 13-33. (Coleção Encontros de Educação).

PION, Étíenne. República e Laicidade. Associação República e Laicidade. [s. d.]. Disponível em: <http://www.laicidade.org >. Acesso em: 12 jun. 2015.

ROCHA, Priscilla Ferreira Nobre. Liberdade religiosa e os limites de intervenção de um Estado laico no âmbito das confissões. 2010. $73 \mathrm{f}$. Monografia (Bacharelado em Direito) - Departamento de Direito, Pontifícia Católica do Rio de Janeiro, Rio de Janeiro, 2010. 